Orijinal Araştırma Makalesi

\title{
Periodontitisli Hastalarda Tükürük ve Dişeti Dokusunda Nitrik Oksit - Arginaz Korelasyonu-Vaka-Kontrol Çalışması
}

\author{
The Correlation of Nitric Oxide and Arginase in Saliva and \\ Gingival Tissue from Patients with Periodontitis- A Case- \\ Control Study
}

Nurdan Özmeriç ${ }^{1}$ (D), Eylem Ayhan Alkan ${ }^{2}$ (D), Tuba Aykan Sargın ${ }^{3}$ (D), Serenay Elgün ${ }^{4}$ (D)

ÖZET

Amaç: Nitrik oksit (NO), birçok fizyolojik ve patolojik proçeste anahtar rolü olan bir moleküldür ve periodontitiste önemli bir role sahiptir. NO, nitrik oksit sentaz (NOS) tarafından argininden sentezlenir. Diğer taraftan arginaz, intrasellüler arginin konsantrasyonunu azaltarak NO üretimini azaltabilir. Periodontitisli bireylerde NOS ekspresyonu yüksek bulunurken, arginaz miktarı düşük saptanmıştır. Çalışmamızın amacı, periodontitisli hastaların tükürük ve dişeti dokusundaki NO ve arginaz arasındaki korelasyonu değerlendirmektir.

Gereç ve Yöntem: Çalışmamızda, 20 periodontitisli hastanın $7 \mathrm{~mm}$ ve üstü klinik ataşman kaybı gösteren bölgelerinden dişeti biyopsileri ve stimüle edilmemiş tükürük örnekleri alındı. Periodontal sağlıkı 11 bireyden ise tükürük örnekleri alındı. Tükürük ve dişeti dokusundaki NO düzeyi nonenzimatik NO kiti ile değerlendirildi. Spesifik arginaz aktivitesi spektrofotometrik olarak belirlendi.

Bulgular: NO, periodontitisli hastaların tükürüklerinde yüksek olarak saptanırken, dokuda düşük olarak izlendi $(p<0.001)$. Arginaz seviyesi ise NO'ya benzer şekilde tükürükte daha yüksekti $(p<0.01)$. Sağlıklı bireylerle karşılaştırıldığında ise tükürük NO düzeyi periodontitiste daha düşük izlendi $(p<0.01)$.

Sonuç: Dokuda NO'in ve arginazın düşük olarak izlenmesi, tükürükte ise sağlıklılara göre yine NO'in düşük bulunması, bu hastalarda periodontal hastalığa yatkınlık oluşturabileceğini düşündürdü.

Anahtar Kelimeler: Arginaz; Nitrik oksit; Periodontal doku Tükürük

\begin{abstract}
Aim: Nitric oxide (NO), is a molecule that plays a key role in many physiological and pathological processes and has an important role in periodontitis. NO is synthesized from arginin by NO synthase (NOS). On the other hand, arginase can downregulate NO production by decreasing intrasellular arginine concentrations In a previous study, an increased NOS expression and decreased arginase production was observed in periodontitis patients.
\end{abstract}

In this study, we aimed to observe the correlation of arginase and $\mathrm{NO}$ in gingival tissue and saliva of patients with periodontitis.

Materials and Method: Our study included 20 periodontitis patients with $\geq 7 \mathrm{~mm}$ of attachment loss. Gingival biopsies and unstimulated saliva samples were obtained from patients. Saliva samples were collected from 11 periodontally healthy subjects. The levels of NO were determined with nonenzimatic NO kit. Specific arginase activity was determined spectrophotometrically.

Results: NO was measured higher in saliva of periodontitis patients compared to that in gingival tissue $(p<0.001)$. Higher amounts of arginase were observed in saliva than in gingival tissue $(p<0.01)$. However, the salivary NO was found lower in periodontitis when it was compared with periodontally healthy subjects $(p<0.01)$.

Conclusion: It was concluded that the decreased production of $\mathrm{NO}$ and arginase in gingival tissue and the lower level of salivary NO in periodontitis compared to periodontally healthy subjects leads to be susceptible to periodontal disease.

Keywords: Arginase; Nitric oxide; Periodontal tissue; Saliva

Makale gönderiliş tarihi: 13.12.2021 ; Yayına kabul tarihi: 29.12.2021

Iletişim: Dr. Nurdan Özmeriç

Gazi Üniversitesi Dişhekimliği Fakültesi, Periodontoloji Anabilim Dalı, Bişkek caddesi 1.sokak No 406490 Emek Ankara

E-posta: nurdan@gazi.edu.tr

${ }^{1}$ Gazi Üniversitesi Dişhekimliği Fakültesi Periodontoloji Anabilim Dalı

${ }^{2}$ Yıldırım Beyazıt Üniversitesi Dişhekimliği Fakültesi Periodontoloji Anabilim Dalı

${ }^{3}$ Serbest hekim, Gaziantep

${ }^{4}$ Ankara Üniversitesi Tıp Fakültesi Tıbbi Biyokimya Anabilim Dalı 


\section{GíRiş}

Periodontitis, dişin destek dokularının yıkımına ve diş kayıplarına yol açan enflamatuar bir hastalıktır. Periodontitisin oluşturduğu bu yıkım, aktif ve pasif evrelerden oluşur. Yıkımın görüldüğü aktif evrenin tanımlanması, periodontal hastalığın izlenmesi ve yıkımın kontrol edilebilmesi açısından önem taşımaktadır. ${ }^{1} \mathrm{Bu}$ nedenle dişeti dokusunda, tükürükte, kan ve dişeti oluğu sıvısında iltihabi mediatörlerin araştırılması önem kazanmıştır. ${ }^{2}$ Nitrik oksit (NO) ve arginaz periodontal patogenezde rol oynayabileceği düşünülen moleküllerdir. NO, indüklenebilen nitrik oksit sentaz (iNOS) enzimi aracılığı ile L-argininin L-sitrüline dönüşmesi sırasında ortaya çıkar. Bu döngü L-argininin, L-ornitine dönüşmesi ile sonuçlanırsa arginaz oluşur

Arginaz, arginin kullanımında NO ile yarışır. ${ }^{3}$ iNOS kaynaklı NO, mikroorganizmalara karşı öldürücü molekül olarak etki göstermektedir. NO üretiminin kontrolü ile enflamasyon regüle edilmektedir. Enflamasyon hücreleri olan nötrofiller ve makrofajlar tarafından salgılanan NO'nun immün düzenlemede ve enflamasyonda önemli rolünün olduğu bildirilmiştir. ${ }^{4-6}$ NO damarsal olaylarda, nöronal fonksiyonların düzenlenmesine kadar pek çok fizyolojik olayda yer alan bir hücre içi sinyal mediatörüdür. ${ }^{7} \mathrm{NO}$ üretimindeki azalma ve artmanın vücut içinde önemli değişikliklere ve belki de patolojilere yol açtığı ileri sürülmüştür. ${ }^{5-7} \mathrm{NO}$ 'nun fizyolojik dengeyi sağlayıCı özelliklerinin yanı sıra enflamatuar hastalıklarda hem koruyucu hem de yıkıcı etkilerinden söz edilmektedir. Lipopolisakkarit ve interferon gama tarafından aktive edilen makrofaj hücreleri ya tek başlarına ya da kombine olarak, Ca bağlı olmayan iNOS indüksiyonuna sebep olmaktadır. $\mathrm{Bu}$ indüksiyon bakteri, mantar gibi hedef hücrelere yönelen NO'nun üretimini arttırmaktadır. ${ }^{8}$

NO vazodilatasyon, enflamasyon, ekstrasellüler proteinlerinin sentezi, proteazların aktivasyonu ve kemik metabolizmasının modülasyonuna katılmaktadır. ${ }^{9-10}$ Bu molekül, kolajen sentezini inhibe ederek, matriks metalloproteaz aktivitesini uyararak kolajen yapım ve yıkımında rol almaktadır. ${ }^{10,11} \mathrm{NO}$ başta fibroblastlar, osteoblastlar, osteoklastlar ve makrofajlar gibi çok sayıda hücrenin fonksiyonlarının düzenlenmesinde görev almaktadır. Bilindiği gibi periodontal hastalık immün sistemin birçok hücresinin birbiriyle etkileşimi neticesinde oluşmaktadır. Konak savunmasının bütün hücreleri periodontal hastalık patogenezinin değişik safhalarında etki göstermektedirler. NO'nun da, bu hücrelerin fonksiyonlarında rol oynadığı için periodontal hastalık patogenezinde etkili olduğu düşünülmektedir. Hem arginazın hem de NO'nun doku ve tükürükte de varlığı daha önceki çalışmalarımızda bildirilmiştir. ${ }^{12,13}$ NO'nun tükürükteki mevcudiyeti çoğunlukla tükürük bezlerinden NO salınmasından dolayıdır. Böylece tükürüğe doğal antibakteriyel özellik sağlar. ${ }^{14}$ Tükürükteki arginaz varlığı bilinmesine rağmen dişeti dokularında arginaz varlığı Güllü ve ark. ${ }^{15}$ 'nın immunohistokimyasal çalışmasında gösterilmiştir. Tükürükte NO azalması, tükürüğün antibakteriyel özelliğini de azaltır. Arginaz, arginin miktarını azaltır ve yüksek miktarda NO üretimini önleyerek enflamasyonda yerini alır. ${ }^{16}$ Arginaz ve nitrik oksitin periodontal hastalıkta tükürük ve dişeti dokularında farklı düzeylerde bulunduğu hipotezi ile bu çalışma planlanmıştır. Hastaların periodontal klinik indeks ölçümleri ile bu biyokimyasal parametrelerin düzeyleri arasında bir korelasyon olabileceği düşünülmüştür.

Çalışmamızın amacı periodontitisli hastaların tükürük ve dişeti dokusundaki NO - arginaz arasındaki korelasyonu değerlendirmektir.

\section{GEREÇ VE YÖNTEM}

Çalışmamıza Gazi Üniversitesi Periodontoloji Anabilim Dalı'na periodontal şikayetlerle başvurmuş, klinik ve radyografik muayene sonrasında periodontitis tanısı konulmuş; sistemik olarak sağlıklı, sigara içmeyen, son altı ay içinde antibiyotik ve anti-enflamatuar ilaç kullanmamış, periodontal tedavi görmemiş 20 gönüllü periodontitis hastası ve yaş ortalamaları 28-55 olan 11 sağlıklı birey dahil edilmiştir. Çalışmamız, Gazi Üniversitesi Diş Hekimliği Fakültesi Etik Kurulu'ndan onay almış ve dahil edilen hastalara, çalışma hakkında bilgi verildikten sonra onamları alınmıştır. Hastalardan ve kontrol grubundan; Plak indeks ${ }^{17}(\mathrm{PI})$, Gingival indeks ${ }^{18}(\mathrm{GI})$, Sondlamada kanama $^{19}(\mathrm{SK})$, Klinik ataşman seviyesi (KAD), Periodontal Cep derinliği ölçümleri (CD), stimüle edilmemiş tükürük örnekleri, periodontitis hastalarından 7 $\mathrm{mm}$ üzerinde cep derinliği bulunan tek köklü dişlerden dişeti biyopsi örnekleri alınmıştır.

Dişeti biyopsileri lokal anesteziyi takiben, başlangıçta herhangi bir tedavi uygulamadan alındı. Biyopsiler 
patolojik cebin yumuşak doku duvarından keskin küretle alındı ve yaklaşık $1 \mathrm{~mm} \times 1 \mathrm{~mm} \times 1 \mathrm{~mm}$ 'lik doku örnekleri elde edildi. Biyopsiler, cep derinliği $7 \mathrm{~mm}$ ve üzeri olan, ataşman kaybı gösteren, yalancı cep mevcudiyeti olmayan bölgelerden ve enflamasyonun klinik belirtilerinin gözlendiği interdental papil bölgelerinden alındı. Sağlıklı bireylerden dişeti biyopsileri alınmadı, karşılaştırma sadece tükürük düzeylerinde yapıldı. Alınan periodontal hastalıklı dokular biyokimyasal olarak analiz edildi. Doku alınan bölgedeki PI, GI, SK, SCD, KAD ölçümlerinin standardizasyon amacıyla benzer olmasına ve kemik içi cep varlığının olmamasına dikkat edildi. Elde edilen dokular biyokimyasal analiz için içerisinde $0.15 \mathrm{M}$ serum fizyolojik bulunan eppendorf tüplerine yerleştirilerek $-20^{\circ} \mathrm{C}$ 'de deney gününe kadar saklandı. Klinik veriler kaydedilmeden önce, bireylerin ağızları suyla çalkalatıldı ve stimüle edilmemiş tükürük, 60 sn'de ve 1.5 $\mathrm{ml}$ miktarında ependorf tüplere toplandı. Toplama zamanı yaklaşık olarak sabah saat 9'du. Örnekler $+4^{\circ} \mathrm{C}$ 'de $15000 \times$ g'de 10 sn santrifüj edildi ve analiz edilene kadar $-20^{\circ} \mathrm{C}$ 'de saklandı.

Tükürük ve dişeti dokusundaki NO düzeyi kolorimetrik non-enzimatik NO kitiyle değerlendirildi (Oxford Biomedical Research, Michigan, USA). Bu kitin prensibine göre sıvı ortamda nitrik oksit hızla nitrit ve nitrata dönüşmektedir. Kolorimetrik non-enzimatik NO kitiyle nitratın nitrite dönüşümü kantitatif olarak ölçülmektedir. Bu şekilde total NO üretimi ölçülebilmektedir. Spesifik arginaz aktivitesi (Chinard metodu) spektrofotometrik olarak belirlenmiştir. ${ }^{20}$ Buna göre enzim aktivitesi IU/ ml olarak ve arginaz tarafından argininin hidrolizinden üretilen ornitin miktarının ölçümüyle tanımlandı. Biyopsi örnekleri enzim aktivitesinin ortaya çıkartılması için ezildi. Karışım (0.5ml) 0.5 mikromol $\mathrm{MnCl}, 10$ mikromol arginine ve 30 mikromol karbonat tampon içeriyordu ve $\mathrm{pH} 9.8$ olarak tutuldu. 15 dakika süreyle $37^{\circ} \mathrm{C}$ de inkübasyondan sonra $0.05 \mathrm{ml}$ supernatan eklendi. Reaksiyon $1.5 \mathrm{ml}$ konsantre asetik asitle durduruldu. $0.5 \mathrm{ml}$ ninhidrin solüsyonu eklenerek kaynayan su banyosunda 1 saat ısıtıldı. Emilim spektrofotometrede 515 nm'de ölçüldü. Arginazın tek birimi $37^{\circ} \mathrm{C}$ 'de 1 dakikada 1 mikromol ornitin üreten enzim miktarı olarak tanımlandı. Her bir örnek iki kez analiz edildi.

Klinik parametreler $\mathrm{PI}, \mathrm{GI}, \mathrm{CD}, \mathrm{KAD}$, SK ve biyokimyasal parametreler ortalama \pm standart sapma olarak değerlendirildi. Klinik ve biyokimyasal parametrelerin korelasyonu, 'Spearman korelasyon katsayısı analizi' ile değerlendirildi. Gruplar arasındaki klinik ve biyokimyasal parametrelerin karşılaştırmasında Mann-Whitney $U$ testinden yararlanıldı.

\section{BULGULAR}

Çalışmamızda, periodontitisli bireylerde başlangıçta herhangi bir tedavi uygulamadan önce NO, arginaz düzeyleri ve bu biyobelirteçlerin klinik parametreler ile ilişkileri araştırıldı. Periodontitisli 20 hastadan ve kontrol grubu olarak alınan 11 bireyden elde edilen tüm ağız klinik parametreler (PI, GI, SK, CD, KAD) ve biyokimyasal parametrelere ait ortalamalar ve aradaki farkın önemlilik dereceleri Tablo 1 ve 2'de gösterildi. Ayrıca tüm ağız, klinik ve biyokimyasal parametreler arasındaki korelasyon Tablo 3, 4, 5 ve 6 'da gösterildi. Periodontitisli hastalardan elde edilen tükürükte nitrik oksit düzeyleri, periodontal dokulara göre istatistik olarak önemli anlamlılıkta yüksek bulundu ( $p<0.001)$, arginaz düzeyi ise yine tükürükte dokuya göre daha yüksekti $(p<0.01)$ (Tablo 1 , Şekil 1). Periodontitisli grupta $G I, C D$ ve $K A D$ düzeyleri, periodontal sağlıklı bireylere oranla daha yüksekti $(p<0.001)$ (Tablo 2). PI, periodontitiste sağlıklılara göre daha yüksek bulundu ancak aradaki fark istatistiki olarak anlamlı değildi $(p>0.05)$. Periodontitis ve sağlıklı bireylerin tükürüklerinde $\mathrm{NO}$ ve arginaz karşılaştırıldığında, periodontitisli bireylerde tükürük-

Tablo 1. Tükürük ve Dişeti Dokusunda Nitrik Oksit ve Arginaz Seviyelerinin İstatistiksel Karşılaştırılması

\begin{tabular}{llll}
\hline & Tükürük & Dişeti dokusu & P değeri \\
\hline $\begin{array}{l}\text { Nitrik Oksit } \\
\text { (nmol/mg) }\end{array}$ & $115.91 \pm 108.33$ & $7.28 \pm 4.49$ & $\mathbf{0 . 0 0 0}{ }^{* * *}$ \\
$\begin{array}{l}\text { Arginaz } \\
\text { (mlU/mg) }\end{array}$ & $174.69 \pm 113.15$ & $102.23 \pm 54.65$ & $\mathbf{0 . 0 0 6} 6^{* *}$ \\
${ }^{* * P<0.01,{ }^{* * *} \mathrm{P}<0.001}$ & & & \\
\end{tabular}

Tablo 2. Periodontitisli ve Sağlıklı Grupta Tüm Ağız Klinik İndeks Ortalamaları

\begin{tabular}{llll}
\hline & Periodontitis & Sağlıklı & P değeri \\
\hline Plak İndeks & $1.015 \pm 0.576$ & $0.6 \pm 0.377$ & 0.241 \\
$\begin{array}{l}\text { Gingival } \\
\text { Indeks }\end{array}$ & $1.303 \pm 0.511$ & $0.244 \pm 0.232$ & $0.005^{* *}$ \\
$\begin{array}{l}\text { Cep Derinliği } \\
\text { Klinik Ataşman }\end{array}$ & $3.414 \pm 0.832$ & $1.787 \pm 0.354$ & $0.007^{* *}$ \\
$\begin{array}{l}\text { Düzeyi } \\
{ }^{* *} P<0.01\end{array}$ & & & \\
& & & \\
\end{tabular}


Periodontitisli Hastalarda Tükürük ve Dokuda Nitrik Oksit ve Arginaz Düzeyleri
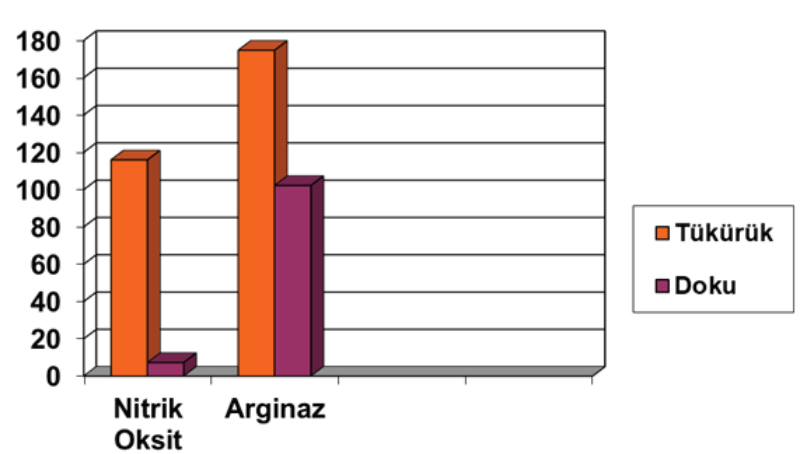

Şekil 1. Periodontitisli hastalarda tükürük ve dokuda nitrik oksit ve arginaz düzeylerinin karşılaştırılması

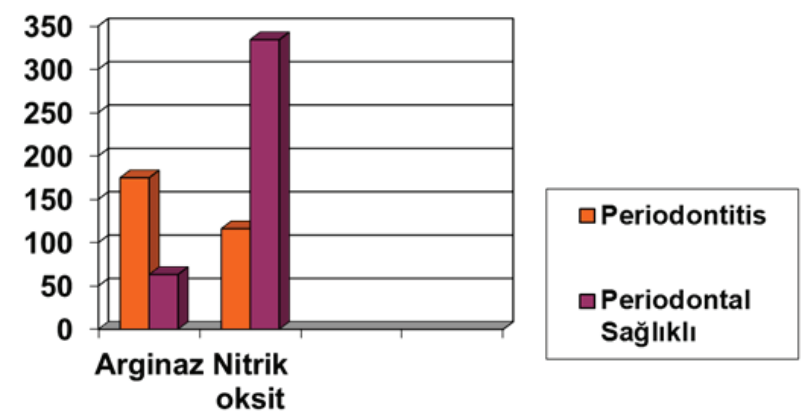

Şekil 2. Periodontitis ve Sağlıklı Grupta Tükürük Arginaz ve Nitrik Oksit Düzeylerinin Karşıllaştııılması

Tablo 3. Periodontitisli Hastalarda Tükürük ve Doku Nitrik Oksit Düzeyleri ile Tüm Ağız Klinik İndeksler Arasındaki Korelasyon ( $r$ )

\begin{tabular}{lllllll}
\hline & NO Tükürük & NO Doku & PI & GI & CD & KAD \\
\hline NO Tükürük & & 0.155 & -0.341 & -0.164 & -0.069 & -0.093 \\
NO Doku & 0.155 & & -0.206 & 0.011 & 0.291 & 0.264 \\
PI & -0.341 & -0.206 & & $0.455^{*}$ & $0.465^{*}$ & $0.465^{*}$ \\
GI & -0.164 & 0.011 & $0.455^{*}$ & & $0.582^{* *}$ & $0.581^{* *}$ \\
CD & -0.069 & 0.291 & $0.465^{*}$ & $0.582^{* *}$ & & $0.983^{* *}$ \\
KAD & -0.093 & 0.264 & $0.465^{*}$ & $0.581^{* *}$ & $0.986^{* *}$ & $0.983^{* *}$ \\
\hline${ }^{*} P<0.05^{* *} \mathrm{P}<0.01{ }^{* * *} \mathrm{P}<0.001$ & & & & &
\end{tabular}

Tablo 4. Periodontitisli Hastalarda Tükürük ve Doku Arginaz Düzeyleri ile Tüm Ağız Klinik İndeksler Arasındaki Korelasyon $(r)$

\begin{tabular}{|c|c|c|c|c|c|c|}
\hline & Arginaz Tükürük & Arginaz Doku & $\mathbf{P I}$ & GI & CD & KAD \\
\hline Arginaz Tükürük & & -0.094 & -0.066 & -0.044 & 0.222 & 0.307 \\
\hline Arginaz Doku & -0.094 & & 0.101 & -0.137 & -0.083 & 0.011 \\
\hline PI & -0.066 & 0.101 & & $0.455^{*}$ & $0.465^{*}$ & $0.465^{*}$ \\
\hline GI & -0.044 & -0.137 & $0.455^{*}$ & & $0.582^{* *}$ & $0.581^{* *}$ \\
\hline CD & 0.222 & -0.083 & $0.465^{*}$ & $0.582^{\star *}$ & & $0.983^{* *}$ \\
\hline KAD & 0.307 & 0.011 & $0.465^{*}$ & $0.581^{* *}$ & $0.986^{* *}$ & $0.983^{* *}$ \\
\hline
\end{tabular}

Tablo 5. Periodontitisli Hastalarda Tükürük ve Dokuda Arginaz ile Nitrik Oksit Düzeyleri Arasındaki Korelasyon

\begin{tabular}{lllll}
\hline & Arginaz Tükürük & Arginaz Doku & NO Tükürük & NO Doku \\
\hline Arginaz Tükürük & & -0.094 & 0.252 & 0.183 \\
Arginaz Doku & -0.094 & & -0.293 & 0.035 \\
NO Tükürük & 0.252 & -0.293 & & 0.155 \\
NODoku & 0.183 & 0.035 & 0.155 & \\
\hline
\end{tabular}

Tablo 6. Sağlıklı Grupta Tükürük Arginaz ve Nitrik Oksit Düzeyleri ile Tüm Ağız Klinik İndeksler Arasındaki Korelasyon

\begin{tabular}{lllllll}
\hline & Arginaz Tükürük & NO Tükürük & PI & GI & CD & KAD \\
\hline Arginaz Tükürük & & -0.039 & 0.594 & $0.671^{*}$ & -0.168 & -0.016 \\
NO Tükürük & -0.039 & & -0.385 & -0.536 & 0.193 & 0.227 \\
PI & 0.594 & -0.385 & & $0.719^{*}$ & -0.029 & -0.071 \\
GI & $-0.671^{*}$ & -0.536 & $0.719^{*}$ & & -0.199 & -0.124 \\
CD & -0.168 & 0.193 & -0.029 & -0.199 & & $0.960^{* *}$ \\
KAD & -0.016 & 0.227 & -0.071 & -0.124 & $0.960^{* *}$ & \\
\hline
\end{tabular}

${ }^{*} \mathrm{P}<0.05,{ }^{* *} \mathrm{P}<0.01$ 
te arginaz yüksek bulunurken $(p<0.05)$, NO düzeyi sağlıklılara göre daha düşüktü $(p<0.01)$ (Şekil 2). Periodontitisli bireylerin tükürük ve doku NO düzeyleri ile tüm ağız klinik indeksler arasındaki korelasyon değerlendirildiğinde, sadece klinik indekslerin kendi aralarında anlamlı pozitif korelasyon gösterdiği bulgulandı (Tablo 3). Bu bulgu, arginaz için de benzerdi (Tablo 4). Periodontitisli hastaların tükürük ve dişeti dokusunda arginaz ve NO düzeyleri arasında anlamlı bir korelasyon izlenmedi (Tablo 5). Sağlıklı bireylerde ise GI ile tükürük arginaz düzeyleri arasında pozitif yönde anlamlı bir korelasyon vardı $(r=0.671, p<0.05)$ (Tablo 6).

\section{TARTIŞMA}

$\mathrm{Bu}$ çalışmanın sonuçlarına göre periodontitisli hastaların tükürüklerinde, sağlıklı gruba göre arginaz enzimi daha yüksek olarak izlenmektedir.

Yüksek arginaz aktivitesinin oral bakteriler için gerekli olan poliaminlerin sentezini arttırdığı öne sürülmüştür. ${ }^{16}$ Sağlıklı grupta periodontitisli gruba göre, tükürükte NO'in yüksek olarak ölçülmesi, tükürük NO artışının sadece enflamasyon sebebiyle olmadığı, yani sadece NOS2 (iNOS) aracılığıyla gerçekleşmemesinden kaynaklanmaktadır.

Tükürük NO kaynağı NOS2 dışında; sinir sonlanmaları, tükürük bezlerinin sekretuvar hücreleri ve tükürük bezi endoteliyal hücreleri olabilir. Bizim çalışmamızın sonuçları, tükürük NO sentezini periodontitisli hastalarda daha düşük olarak bulgulayan Auer ve ark. ${ }^{21}$ 'nın çalışmasıyla uyumlu olarak izlenmiştir. Bu bulgu, periodontal dokularda NO sentezinin arttığını bulgulayan diğer çalışmalarla çelişmektedir. ${ }^{15,22}$ Matejka ve ark'nın²2 yaptığı bir çalışmada, dişeti örnekleri, 21 periodontitisli ve 16 sağlıklı kontrol grubunu oluşturan bireyden alınmıştır. Dokular floresan dedektörlü high performance liquid chromatography (HPLC) tekniği ile değerlendirilmiştir. Bu çalışmanın sonucunda NO sentezinin enflame periodontal dokularda arttığı bulgulanmıştır. NO sentezinin artışı dokudaki yüksek konsantrasyonlardaki L-arginin ve L-citrullin'e bağlanmıştır çünkü $\mathrm{NO}, \mathrm{O}_{2}$ varlığında L-arginin'in L- citrullin'e dönüşümü neticesi sentezlenmektedir22. Sonuçlarımızın bu çalışmayla uyumlu olmaması, kullanılan NO ölçüm yönteminin farklılığından kaynaklanabilir. NO, moleküler oksijen varlığında stabil değildir ve hızlı, spontan olarak çeşitli nitrojen oksitleri üretecek şekilde kendi kendine okside olur. ${ }^{23} \mathrm{Bu}$ nedenle hücrelerde ve dokularda NO varlığının tespitinde zorluk çekildiği bilinmektedir. Bizim çalışmamız tükürük ve periodontal dokular arasında NO ve arginaz üretimini karşılaştıran ilk çalışmadır. Periodontitisli grupta, doku NO'i, tükürük NO'ine göre daha az düzeyde saptanmıştır. Bu NO'in lokal olarak baskılandığını düşündürmektedir.

Özmeriç ve arkadaşlarının ${ }^{12}$ yaptığı bir çalışmada, 20 kronik periodontitisli hastadan ve 15 sağlıklı hastadan tükürük örnekleri alınmıştır. Tükürüğün total protein miktarı, spektrofotometrik enzim analizi tekniğiyle ölçülmüştür. Sonuçta hastalıklı grupta tota protein miktarında belirgin bir artma yokken, arginaz miktarında belirgin artış olduğu bildirilmiştir. Periodontal indekslerin periodontitisli hastalarda, kontrol grubuna göre yüksek bulunduğu, fakat tükürüğün içeriği ile bir korelasyon göstermediği ayrıca arginaz ile total protein miktarı arasında bir korelasyon bulunmadığı açıklanmıştır. Arginaz aktivitesi, deney grubunda kontrol grubuna oranla yüksek olmasına rağmen total protein miktarında belirgin bir farklılık bulunmadığı savunulmuştur. Sonuçta yüksek tükürük arginaz aktivitesi periodontitisli hastalarda gözlenmiş, bunun da poliaminlerin üretiminde artışa yol açtığı, böylece bakterilerin büyümesine ve dolayısıyla hastalık sürecine katkıda bulunduğu öne sürülmüştür. ${ }^{24}$ Bizim çalışmamız da daha önceki çalışmamızın bulgularını destekler şekilde tükürük arginaz düzeyleri periodontitisli grupta, sağlıklılara göre daha yüksek saptanmıştır. Tükürük ve serumda nitrik oksit düzeyini periodontitisli bireylerde karşılaştıran bir çalışmada hem tükürük hem de serumda nitrik oksit düzeyinde istatistiksel anlamlı bir korelasyon saptanmıştır. ${ }^{25}$ Benzer bir korelasyon bizim çaıışmamızda periodontal dokular ve tükürük arasında gösterilememiştir.

Sonuç olarak, tükürükte NO ve arginaz düzeylerinin dokudaki miktarlarına göre daha yüksek bulunması, tükürüğün sistemik etkilere (sistemik hastalıklar, tükürük bezi kaynaklı diğer sistemik durumlar, beslenme gibi) daha açık olduğunu, doku kaynaklı NO ve arginazın ise periodontal hastalık etkilerini tükürüğe göre daha iyi yansıttığını düşündürmektedir. Yine hem doku hem de tükürükte NO ve arginaz düzeyleri arasında bir korelasyon izlenmemesi, beklenildiğ üzere ortak substrat kullanan bu iki biyobelirteçin, substrat tüketimi dışında başka patobiyolojik yolaklardan etkilendiğini akıla getirmektedir, bu durumda 
hücreler arası iletişim, sitokin gibi diğer haberleşme sinyalleri üzerinden değerlendirilmelidir.

\section{Teşekkür}

Bu çalışma, Gazi Üniversitesi Bilimsel Araştırma Projeleri desteği (03/03-13) ile gerçekleştirilmiştir.

\section{KAYNAKLAR}

1. Socransky SS, Haffaje AD, Goodson JM, Lindhe J. New concepts of periodontal disease. J Clin Periodontol 1984;11:21-32.

2. Page RC. Host response tests for diagnosing periodontal diseases. J Periodontol 1992;63:356-66.

3. Bredt $D$, Schmidt $H$. The Citrulline Assay, Methods in Nitric Oxide Research, John Wiley, New York; 1997.

4. Nussler AK, Billiar TR. Inflammation, immunoregulation, and inducible nitric oxide synthase. J Leukoc Biol 1993;54:171-8.

5. Stichtenoth DO, Frölich JC. Nitric oxide and inflammatory joint diseases. Br J Rheum 1998:37:246-57.

6. Miller MJ, Sandoval M. Nitric Oxide 3. A molcular prelude to intestinal inflammation, Am J Physiol 1999;276:795-9.

7. Wink DA, Mitchell JB. Chemical biology of nitric oxide: insights into regulatory, cytotoxic, cytoprotective mechanism of nitric oxide. Free Radic Biol Med 1998;25:434-56.

8. Moncada SR, Nistico G, Higss EA. Biolojical Relevance of the L-arginine: Nitric Oxide Pathway, Nitric oxide: Brain and İmmune system, S Moncado, G Nistico, E. A. Higgs eds. Portland Press London 1992. p. 1-8.

9. Moncada SR, Palmer MJ, Higgs EA. Nitric oxide: physiology, pathophysiology and pharmacology. Pharmacol Rev 1991;43:10942.

10. Trachtman H, Futterweit $S$, Singhal P. Nitric oxide modulates the synthesis of extracellular matrix proteins in cultured rat mesangial cells. Biochem Biophys Res Commun 1995;207:120-5.

11. Murrell GAC, Jang D, Williams RJ. Nitric oxide activates metalloprotease enzymes in articular cartilage. Biochem Biophys Res Commun 1995;206:15-21.

12. Özmeriç $N$, Elgün $S$, Uraz $A$. Salivary arginase in patients with adult periodontitis. Clin Oral Invest 2000;40:21-4.
13. Dunnan C, Douglas H, Johnston P et al. Chemical generation of nitric oxide in mouth from the enterosalivary circulation of dietary nitrate. Nature med 1995;1:546-51.

14. Kankanian AL, Akopov SE. The stimulation of nitric oxide synthesis as possible protective function of the saliva and its disorders in periodontol disease. Stomalolgiia 1996;75:19-21.

15. Güllü C, Ozmeric N, Tokman B, Elgün S, Balos K. Effectiveness of scaling and root planing versus modified Widman flap on nitric oxide synthase and arginase activity in patients with chronic periodontitis. J Periodontal Res 2005;40:168-75.

16. Cook HT, Jansen A, Lewis S, Largen P. Arginine Metabolism in Experimental Glomerulonephritis: İnteraction between Nitric Oxide Synthase and Arginase. Am J Physiol 1994;267:646-53.

17. Silness J, Löe H. Periodontal disease in pregnancy. II. Correlation between oral hygiene and oral condition. Acta Odontol Scand 1964;121-35.

18. Löe $\mathrm{H}$, Silness J. Periodontal disease in pregnancy. I. Prevalence and severity. Acta Odontol Scand 1963;21:533-51.

19. Ainamo J, Bay I. Problems and proposals for recording gingivitis and plaque. J Int Dent 1975;25:229-35.

20. Chinard FP. Photometric estimation of proline and ornithine. J Biol Chem 1952; 199:91-5.

21. Auer A, Aleksic J, Ivic-Kardum M, Auer J, Culo F. Nitric oxide synthesis decreased i periodontitis. J Clin Periodontol 2001;28:565-8.

22. Matejka M, Portyka L, Ulm C, Solar P, Sinzinger H. Nitric oxide synthesis is increased in periodontol disease. J Periodont Res 1998;33:517-8.

23. Beckman JS, Crow JP. Pathological Implications of Nitric Oxide, Superoxide and Peroxinitride Formation. Biochem Soc Trans 1993; 21:330-4.

24. Henkens YM, Van Der Weijden FA, Van Der Keijbus PA. Effect of periodontal treatment on the protein composition of whole and paratid saliva. J Periodontol 1996;67:205-12.

25. Sundar NM, Krishnan V, Krishnaraj S, Hemalatha VT, Alam $\mathrm{MN}$. Comparison of the salivary and the serum nitric oxide levels in chronic and aggressive periodontitis: a biochemical study. $J$ Clin Diagn Res 2013;7:1223-7. 